PAWEe ZieLińSKI

Uniwersytet Humanistyczno-Przyrodniczy im. Jana Dtugosza

$w$ Częstochowie

\title{
THE RELATIONSHIPS AND DIFFERENCES OF THE KANTIAN PHILOSOPHY AND PEDAGOGY IN REGARD TO POSTMODERN PEDAGOGIC
}

\begin{abstract}
Zieliński Pawel, The Relationships and Differences of the Kantian Philosophy and Pedagogy in Regard to Postmodern Pedagogic [Podobieństwa i różnice pomiędzy filozofią i pedagogiką Kanta a pedagogiką ponowoczesną]. Studia Edukacyjne nr 48, 2018, Poznań 2018, pp. 115-132. Adam Mickiewicz University Press. ISSN 1233-6688. DOI: 10.14746/se.2018.48.8

The aim of the study is articulated in the title. The author is reconstructing Kantian philosophy and pedagogic, the thesis of postmodernism and post-modern pedagogic and indicates the relationships and differences of those two systems. Both Kant and the Baden-based neo-Kantians enabled the emancipation of the humanities. The Kantian model of pedagogy was the basis for pedagogic directions, belonging to the meta-theory of humanistic education and critical pedagogy, especially the postmodern one. There are clear links with Kantian ideas of pedagogy, the way to capture the role of dignity, knowledge and freedom in the morality of a human being. There are also significant differences: Kant did not include to his pedagogy social, political and pluralistic questions, which are so important in postmodern pedagogy.
\end{abstract}

Key words: Kantian philosophy and pedagogy; postmodern pedagogy; moral education; identity of the person; humanistic pedagogy

\section{The introduction, purpose and methodological assumptions of this thesis}

The beginnings of modern pedagogy in Poland were recently recovered in the pedagogical thought of Johann Friedrich Herbart (1776-1841). In his scientific system of pedagogical goals of education have been derived from the ethics and methods of implementation referred to the psychology. Herbart pointed out to directing, teaching and discipline as three "foundations 
of education". Treating those points as the main goals of education, which is shaping the moral character of the student could be realized. Herbart is considered to be representative of the positivist pedagogy, ${ }^{1}$ although his years of life and some opinions, such as those related to the objectives of education, do not fall within positivism. It herbartian pedagogy as a pedagogical movement formed in the second half of the nineteenth century, referring largely to the views of Herbart but also to other sources, has become a positivist mainstream, clearly emphasizing collectivist way of thinking about education. ${ }^{2}$ Among its main values are mentioned: conservatism, socialization, authority, intellectualism, continuity and long-term perspective and the other. ${ }^{3}$

However, in the recent decades reputable Polish scientists-educators, as Slawomir Sztobryn, Andrzej de Tchorzewski or Bogusław Śliwerski have pointed to earlier sources of scientific pedagogy, in the philosophical and pedagogical achievements of another German scholar - Immanuel Kant (1724-1804). It was the Herbart's predecessor at the University of Königsberg, where he was directing (among other activities) the philosophy and pedagogy cathedrals and was recognized as the scholar, who pointed out the direct links between philosophy of scientific pedagogy. Kant was the first person in Europe since 1776 was giving lecture of pedagogy. Shortly before his death, he published a work about pedagogy, in which he explained his own understanding of education.

The reference to Kant's scientific achievements allow interpret contemporary pedagogy more as a science humanistic than social. The main ideas and goals are more idealistic than materialistic, as well as their democratic and not authoritarian character. Also it's worth to underline emphasize the subjectivity not objectivity in education. The deviation from the standards of positivist and scientistic modern pedagogy is not complete, in fact, now we can strongly indicate the two distinct trends: the positivist-scientistic and humanistic. Modern directions of teaching, which is a few dozen, to a greater or lesser extent are associated with these main trends of pedagogy. Robert Kwaśnica made a thorough characterization of two ways of dealing with reality, including educational, understandable. He described them as rationality, understand as making-sense structures and characterized in details the two opposing rationality: the adaptive and emancipatory ${ }^{4}$. In the context of education, this

${ }^{1}$ T. Hejnicka-Bezwińska, Pedagogika pozytywistyczna, [in:] Pedagogika, t. 1 Eds. Z. Kwieciński, B. Śliwerski, Warszawa 2004, p. 208.

${ }^{2}$ M. Somr, L. Hruškova, Herbart's Philosophy of Pedagogy and Educational Teaching, Studia Edukacyjne, 2014, 33, p. 413.

${ }^{3}$ T. Hejnicka-Bezwińska, Pedagogika pozytywistyczna, p. 211.

${ }^{4}$ R. Kwaśnica, Dwie racjonalności. Od filozofii sensu ku pedagogice ogólnej, Wrocław 1987, p. 16-17, 59 . 
scholar wrote about the dispute of two pedagogics, which one comes from the adaptation values and the second of emancipation. Pedagogy are different in conception of the objectives and tasks of education. Kwaśnica wrote:

For the first pedagogics, the objective is the development of the juvenile, understood as an adaptation to the existing life conditions. Using the language of modern development theory we would say that education is the upper limit of development in the identity of conventional (Kohlberg) or otherwise - in the roles of identity (Erikson). The purpose of education is, according to the pedagogic, shaping the students in desirable and inviolable personal patterns, recognized by their community. The second pedagogic is in favor of post conventional identity, autonomous, shaping the level of universal values. It's purpose of education is development, understood as self-realization and the task of education - not maintaining the existing order, but promotion wider change of man and the world..$^{5}$

The opposition also applies to pedagogical issues such as: the essence of educational changes, the understanding of pedagogical interactions, methods, means and forms of upbringing, education in terms of knowledge and understanding of the concept of aid. ${ }^{6}$

The above-mentioned, contemporary Polish scientists-educators and Zbigniew Kwieciński, Lech Witkowski, Zbyszko Melosik, Tomasz Szkudlarek and others, who describe themselves as culture educators, driven by emancipation or anti-authoritarian, they see postmodern education as a chance of positive change for pedagogy in the way of developing the moral and personality competencies of the students to support their spiritual development and the genuine democratization of society. This change would apply also indicate other, more primitive sources of pedagogy as a science, its main objectives and conditions of highlighting the value of knowledge and freedom in humanistic pedagogic, which grew on the Kant's achievements and culture pedagogic and other fields of pedagogy with similar assumptions. All above mentioned fields of studies are based on meta-theories of humanistic and critical pedagogy, that is, ideologically similar, in contrast to pedagogics: behavioral and conservative, derived from herbartian and naturalistic sciences, supporting the present model of education and training. ${ }^{7}$

From the methodological point of view, presented these is based on hermeneutics research and comparative analysis. In this article I tried to find out the relationships and differences in the assumptions of Kantian philosophy, especially ethics, anthropology and education, as essential to the constitution of humanistic education, with the theories of contemporary postmodern pedagogic, grasped as a valuable pedagogical direction by a group of Polish hu-

\footnotetext{
${ }^{5}$ Ibidem, p. 101.

${ }^{6}$ B. Śliwerski, Wspótczesne teorie i nurty wychowania, Kraków 1998, p. 27-28.

${ }^{7}$ Ibidem, p. 15.
} 
manities teachers. I'm investigating the main objectives of both Kantian and postmodernism philosophy and pedagogy and in the field of interpretation I compare them together, searching for their mutual relationships, to realize the above-cited goal of my research.

\section{The Kantian philosophy and pedagogy}

Immanuel Kant was primarily a philosopher, however he dealt with many other sciences, such as mathematics or geography. ${ }^{8}$ As a philosopher, in different periods of life he was under the influence of Jean Jacques Rousseau's ideas (1712-1778) and David Hume (1711-1776). Kant was under a great impression of Rousseau's Social Contract, describing the political utopia of the ideal democracy. As the author of this work claimed, democracy could be led by the people's act of free will, making any revolutionary changes as its sole discretion. Thanks to the social contract, law legitimizing social inequality had to be abandoned or rejected adopted (Christian and liberal), because so far the states protect the interests of the wealthy, which owned the land and property as well as numerous of political privileges. The freedom in Rousseau's meaning had an extremely anty-individualist and collectivist character. The unit had to be forced into freedom by the public, which creates a new state. The power is there democratic (author advocated the use of only direct democracy), the individual is subordinated by the general fixed laws as in a totalitarian state, because generally the public is regulating every aspect of life in the country. ${ }^{9}$ On the another hand, Hume as a philosopher argued with Cartesian rationalism and tried to base all knowledge on experience. Eventually he has questioned the possibility of objective knowledge as object is carried out by separate the knowing subject, opting for the relativity of knowledge. Furthermore, analyzing the systems of morality he noticed that on certain facts grows interpretation systems, sometimes strongly different from them, treated as mere facts and what cannot be the same. Today in philosophy and other sciences separates facts from values.

Kant, in his famous and difficult in the reception, Critique of Pure Reason took up the terms of cognition. The only source of knowledge is experience through which science can recognize occurrence - phenomenal, but is unable to penetrate the things in themselves - noumenon. The knowing mind perceives phenomenal in time and space, as well as thinking about them, combining

${ }^{8}$ Some text is based on: P. Zieliński, Kantowskie inspiracje pedagogiki humanistycznej, Prace Naukowe Akademii im. Jana Długosza w Częstochowie. Rocznik Polsko-Ukraiński, 2014, 16, p. 57-79.

9 J.J. Rousseau, Umowa społeczna, trans. A. Peretiatkowicz, Kęty 2002, p. 82. 
them with the categories of the intellect. These categories are the same for all people and ultimately determine the object of cognition. Experience is a synthesis of the data eye (sensory) and concepts. Outside of the experience of the mind is unable to know anything. ${ }^{10}$

However, in the field of morality, practical mind (not subject to specified limitations), or morality, shows the behavior of the obligation under the assumption that people should be guided by the categorical imperative, which means that the mind rules the inclinations. This leads to the situation when unit do what is good for others and for himself but the basis is the individual's own will (autonomy). This autonomy makes a choice and responsibility. Kant believed that man lives and belongs to two worlds: the natural as being sensual and experiential and smart, where reason can decide and make it being free. In a world of intelligent, free from coercion, there is morality identified with the practical mind, which is the postulate of freedom. Other demands of reason are immortal soul and God, who ultimately reward good deeds, often requiring sacrifices and other world ensure harmony between virtue and happiness. In Kant's philosophical anthropology there is a transcendental dimension of humanity, associated with dignity. Man as a person has dignity and cannot bring his existence into only in the world of nature, in the experiential dimension. Even the sense of beauty, free from selfishness and self-interest, providing feelings of pleasure indicates that human nature goes beyond the natural world. Anthropology, therefore, should carefully investigate the issue improvement of mankind in its process of development of civilization. ${ }^{11}$

In another thesis Justification Metaphysics of Morals, which was a precursor of Critique of Practical Reason, Kant wanted to quickly create a nomenclature reinforcing the category of conscience because of his conviction about the threat of the virtues of the human being many temptations. Kant wanted to support each questioner as it should be, rather than creating new moral principles, which allow them to better philosophical understanding. The basis of Kant's moral propositions are synthetic judgments a priori - therefore the existing reality, allowing to be explore, universal, and necessary. Kant explained the same morality as a source of human behavior combined with good will and duty, as well as the moral law, which directs the proceedings, although it is not an empirical motivating action. In the remainder of the text he has discussed the correct metaphysics of morals, pointing to no material, but the formal nature of the moral law, binding the will to reason. Theorem moral good will - the basis of ethics, standing much higher than any inclinations, belonging to every man, triggered by enlightenment. The men's mind is used p. 125.

${ }^{10}$ G. Durozoi, A. Roussel, Filozofia. Stownik. Pojęcia, postacie, problemy, Warszawa 1997,

11 Ibidem, p. 126. 
mostly in matters of morality, can restrain the negative tendencies and guided by rational motives. Only deeds filled with duty, so that a person agrees with him, are moral. Kant has also analyzed the various types of heteronomous morality, which ultimately found to be erroneous, because they were based on strangers factors, pointing to the genuine of an autonomous morality. He has also distinguished between two kinds of imperatives: hypothetical, demanding action due to the selected destination and categorical, universally applicable, demanding action because of the act itself: "Proceed as if you wanted the maxim of your will to become a universal law." In the last part of the thesis, Kant took into consideration the concept of freedom, without it the operation of the principle of autonomy could not exist and freedom itself was a metaphysical problem decidable in a practical, rather than theoretical use of reason. ${ }^{12}$

In the Critique of Practical Reason, the next and the main Kant's ethics cause, recurring and growing number of theses from previous thesis, the author established the existence of an immortal soul and God, but do not try to prove it. He regarded them as products of reason, forming human experience and organizing them, giving it an overall sense. Theoretical or pure mind is not able to solve metaphysical problems, in contrast to the practical one. The first generates the ideas and the other operates on demands such as: freedom, God, or immortal soul. The most important in the human's procedure is to be guided by the categorical imperative, the only one recognized by Kant's moral principle of a formal nature. There is no guideline what exactly how to behave, it's only a general principle governing human behavior. Morality can only occur when a person is free, if he will be determined, the morality would be superfluous. The freedom is a postulate, like the immortal soul and God. Based on these postulates human being can morally improve and achieve a sense of happiness. Any moral norms, obligations and prohibitions, Kant advocated output of the categorical imperative. ${ }^{13}$ At the end of life, Kant also introduced a less general than the categorical imperative - imperative of duty, binding behavior with imposed place in the education in the society. The moral thing to do is what is done with the duty, not of his own desire, even in a Criticism of Judgment, devoted to the study of aesthetic judgment, Kant argued that every work of art should be judged as a product of autonomous selflessly, without any external references except one - reference to morality. ${ }^{14}$

Kant has articulated his pedagogical beliefs in a consistent manner in the end of his life in the thesis: Anthropology from a practical point of view, in

\footnotetext{
${ }^{12}$ Ibidem, p. 126-127.

${ }^{13}$ I. Kant, Krytyka praktycznego rozumu, trans. J. Gałecki, Warszawa 2011.

${ }^{14}$ I. Kant, Krytyka władzy sądzenia, trans. J. Gałecki, Warszawa 1986.
} 
1798 and especially in essay About pedagogics, which was released in 1803. In Kant's opinion, only the a man is a subject for the education, which justifies its anthropology, according to which man can attain humanity only as a result of education, procedures culturally shaped as a duty, not coercion. The education is both nutrition and maintenance, as well as exercise, understood as disciplining as well as teaching and learning. So the first step in the process of education is to nurture, the next to exercise. The idea is that the child will be able to turn his "animalism into humanity", or turn his anomia wildness responsible for antagonistic and destructive behavior for the behavior of controlled and planned. In this way possessed talents, ethical and spiritual life of man will be developed. The school's responsibility is not only teach but also to practice the children to a quiet seat and exact performance of selected works, and thus the practice of self-control and resist attempts to immediately implement their own desires. This is an exercise in discipline is used to protect both the individual and the society from animal behavior, human wildness is domesticated. Teaching and education are treated as the cultivation of human culture since the person acquires the skills, some of which like writing and reading, has a fixed application and part of them is only used for a clearly defined purpose. ${ }^{15}$ Kant opposed to provide completed information to the students. In his opinion knowledge should be extracted, using the Socratic and analytical method. ${ }^{16}$ A certain kind of culture, called by Kant the civilization, is designed to help man to fit into human society, obtaining the respectability, being liked. This involves the acquisition of prudence. Also, and this is the most important in the process of education, morality should be developed. Kant pointed out that although the times are a period of discipline, culture and civilized, moralizing is still missing. ${ }^{17}$ According to Kant, pedagogic is divided into physical and practical. The first one primarily supports the development of a child by nurturing and care, and the second deals with practical education or moral. Kant wrote about it as follows:

Practical or moral education is the one which should shape the man, so that he could live as a freely acting unit (...). It is bringing to freedom, education of freely acting human being who will know how to keep himself and become a member of society, but having respect for their intrinsic value. ${ }^{18}$

In education the most important is to strive for the development of the moral side of man, for the extraction of "autonomous" freedom, which stems

${ }^{15}$ W.W. Szczęsny, Kant Immanuel, [in:] Encyklopedia pedagogiczna XXI wieku, vol. 2, G-七, Ed. T. Pilch, Warszawa 2003, p. 522-523.

${ }^{16}$ S. Sztobryn, Stowo wstępne, [in:] I. Kant, O pedagogice, Łódź 1999, p. 21-22.

17 W.W. Szczęsny, Kant Immanuel, p. 523.

${ }^{18}$ I. Kant, O pedagogice, trans. D. Sztobryn, Łódź 1999, p. 54-55. 
from its internal forces and thus Kant opposed his idealistic concept of education to empirical and practical. ${ }^{19}$ Kant stated that without freedom there is no moral culture, the conduct by the rules. As early as possible, children should learn to distinguish good from evil, but they should not be punished at the same time. Morality, which for Kant was something sacred and sublime, cannot be imposed, identified with the discipline. Moral education is primarily the formation of human character. Any progress of humanity can only happen through education, a person only through education can develop their humanity. Human being is raised by other people and only the best of them should become his educators. The process of education is a collective effort, where an important role act wealthy people. Kant was binding education with the concept of perfection, assumed that each generation will increasingly improve humanity. The process of education act as improving human nature, there is also a great mystery, but also the key to a better future for humanity. ${ }^{20}$

Part of Polish educators-pedagogues, especially S. Sztobryn, B. Śliwerski and before Sergiusz Hessen and others, for years have sought to restore Kant's rightful place in pedagogic, previously occupied by Johann Friedrich Herbart. Herbart was considered as the "father" of scientific pedagogic, and as Sztobryn wrote, "he is present in all studies textbook" and "he is the author of a rather flat, methodical instructions for the teacher, when skipping his affiliations Kantian." ${ }^{21}$ For the Polish pedagogues, Kant is a "border character" because his philosophy of criticism and questions about the legitimacy of science, including education, has started a period of scientific reflection on pedagogics. An important implication of Kant's philosophical pedagogy is currently the issue of freedom and coercion in education. In Kant's opinion, morality is not possible without freedom. The sentence was shared among others Polish-known educator Henryk Rowid, who claimed that heteronomy is not able to "create" the moral education of man, only autonomy is capable to do it. Thus, Kant not only put the main problem of the antinomy of education, but also solved it. ${ }^{22}$ According to Sztobryn, Kant also adjudged another antinomy of pedagogic, concerning the individualism or collectivism primacy in education. Kantian finding has a personality dimension, although both factors coexist, separately they are not able to complete or implement process of education. ${ }^{23} \mathrm{~A}$ person is morally developing by both individualistic and collectivist, but the choices and way of life is decided by unit itself in the

19 A.M. de Tchorzewski, Teoria wychowania, [in:] Encyklopedia pedagogiczna XXI wieku, t. 6, Su-U, Ed. T. Pilch, Warszawa 2007, p. 566-567.

${ }^{20}$ W.W. Szczęsny, Kant Immanuel, p. 523.

${ }^{21}$ S. Sztobryn, Stowo wstępne, p. 5.

${ }^{22}$ Ibidem, p. 31-32.

${ }^{23}$ Ibidem, p. 35. 
creative process of internal change, which is a modern vision of education. ${ }^{24}$ It is worth to note, what Kant wrote about education, it's basically about the education of boys, not girls, though usually it is believed that his pedagogic affects both sexes and perhaps philosopher saw no issue of gender segregation in the educational process, as the spirit of the times and the society in which he lived. The equal civil rights, especially political, but also in the field of education were established for women in various countries until the early twentieth century.

\section{Postmodern education is an opportunity for modern pedagogy?}

Postmodern education as a pedagogical direction is perceived differently by Polish pedagogues. Similarly, the reception and evaluation of the postmodernism significance as a cultural and social movement or even era in the development of the modern world.

American sociologist, literary and cultural symbolic theorist Frederic Jameson (born in 1934.), ideologically linked with the Frankfurt School, which became widespread in the sixties the concept of post-modernism, postmodernism sees culture negatively, was seeing it as a late phase of consumer and multinational capitalism. In the foreground, consumption is the most visible, capital spreads far beyond the sphere of production in the various fields of life and also goes to the culture, where it loses its depth and produces "exterior" as a product. ${ }^{25}$

The French philosopher and post-Marxist, Jean-François Lyotard (19241998) argued that modern science is no longer open to new ideas. He has also questioned the achievements especially philosophy, ordering the other studies to pursuit and use of meta-strict rules of scientific method, when philosophy itself does not apply them. He said that the new task of philosophy is to provide assistance in resolving conflicts that arise from diversity. In post-modern society, knowledge "certain and orderly" disappears and strictly defined rules of life are no longer in use. In their place appear pluralism of ideas and creative abrasion of the posts. ${ }^{26}$ Lyotard sought to show the direction of postmodernism as a valuable, useful in solving the pressing problems of the modern world. Rupture understood as abrasion of the differences is valuable

${ }^{24}$ Ibidem, p. 37.

25 F. Jameson, Postmodernizm i społeczeństwo konsumpcyjne, trans. P. Czapliński, [in:] Postmodernizm. Antologia przekładów, Ed. R. Nycz, Kraków 1997, p. 212.

26 J.F. Lyotard, Kondycja ponowoczesna. Raport o stanie wiedzy, trans. M. Kowalska, J. Migasiński, Warszawa 1997, p. 131. 
because it dethrones one vision of the world, set out as the "big story", and thus is an fair activity. Lyotard's thesis in philosophy of language are difficult to read but they contain applications of universal character. It is better to consider all the discourses are unfair and the clue of dispute overcome is not a consensus or any final decision, but only its "neutralization". Maintenance of pluralism positions seems to be way out of the situation and prevent totalitarianism, which may arise if it was considered appropriate only one post. ${ }^{27}$

Deconstructionism of Jacques Derrida (1930-2004) was rooted on the ground of postmodernism, indicating the need to focus on "the text itself", without considering the context of copyright or civilization..$^{28}$ Also it was allowed the inquiry to the opposite meanings announced by acting or disclosure of hidden meanings by conducting discourses.

For Rychard Rorty (1931-2007) all discourses are equal and the variety of views and tolerance were essential not only for academic universities, but even in a democratic society. Rorty's "Contingency" means questioning one of vision of the world, and the attitude of "ironist" questioning and rejecting authority. Indicated by him, the "culture of irony" was to serve the creation of an atmosphere of freedom, allowing for "units self-creation" in democratic education. ${ }^{29}$

As well as other contemporary thinkers greatly influenced the perception of postmodernism. Paul Michel Foucault (1926-1984), French philosopher, historian and sociologist has questioned the teleological understanding of history, moreover inquired the links between knowledge and power, pointing to such compounds with psychiatry, sexuality and the penitentiary system (Foucault). Austrian philosopher Paul Feyerabend, Karl (1924-1994) has challenged the legitimacy of the current philosophy of science, in a certain period of life he was also a supporter of the relativistic approach in the theory of knowledge and cultural analysis, then he became a critic of relativism. Jean Baudrillard (1929-2007), French philosopher and sociologist, has created the theory of simulacra, simulating reality of images, which have no real existence, but being in the process of emancipation enter the world interact, causing real symptoms, as those caused by actual events. In this way, hyper-reality emerges, where you cannot separate from each other longer ontological and character phenomena. Zygmunt Bauman (1925-2017), Polish sociologist and philosopher, one of the concept of liquid modernity creators, has also developed personal characteristics of contemporary de-

${ }^{27}$ J.F. Lyotard, Poróżnienie, trans. B. Banasiak, Kraków 2010.

${ }^{28}$ S. Wołoszyn, Nauki o wychowaniu w Polsce w XX wieku. Próba syntetycznego zarysu na tle powszechnym, Kielce 1998, p. 137.

${ }^{29}$ Z. Melosik, Pedagogika pragmatyzmu, [in:] Pedagogika, t. 1, Eds. Z. Kwieciński, B. Śliwerski, Warszawa 2004, s. 320-321. 
signs, he has mention the pilgrim as a model of the era of modernism and postmodern four patterns: stroller, vagabond, the tourist and the player. Those roles, in the era of postmodern occur simultaneously in one person. Pilgrim wants to realize his inherent potential, discover his own identity, as Descartes and Kant pointed or build it over a lifetime, as suggests Friedrich Nietzsche, Martin Heidegger and Jean-Paul Sartre. Episodic character of interpersonal contacts in postmodern era symbolizes The Stroller, having no past and no future. The Hobo is still chasing variety, he is not so much interested in a goal, but the stages of achieving it. The Tourist is looking for new experiences, but has support in the home to which he returns. The Player plays still the game of survival, lasting foundation are missing in his life, he might be surprised by something unexpected, he must therefore demonstrate the cunning and win the fight with others, hostile units. ${ }^{30}$ Finally, a man in postmodernism appears in a "twinkling" way, as he do not have a permanent identity, he lives in varying conditions in an atmosphere of distrust and threat, from time to time indulging in pleasures.

Also in Polish pedagogy, there are varied reception of postmodernism. Some educators and historians of education poses acute charges to post-modernity, mostly related to questioning or at least limiting the role of knowledge and learning. Skepticism and distrust have characterized here especially humanists who are not able to comprehend specializing in science and the process of atomization of modern scientific research. The rejection of universal truth and synthesis, fragmentation and pluralism lead to the negation of the existing education and heritage pedagogic. Bizarre example is to be here anti-pedagogic, which completely negates all the achievements. The perception of man only in the sense of nature, without regard to transcendence, as well as the rejection of past authorities and the importance of great value cannot be accepted by the part of scientific world. ${ }^{31}$

Only the question is if this marks a postmodern pedagogy? Without a doubt, the Polish pedagogic it is regarded as a contemporary pedagogical direction, performing under the name of pedagogic (in) post-modernity or the postmodern trends. ${ }^{32}$ Both Stefan Wołoszyn and T. Szkudlarek primarily relate to each other: postmodernism, politics and pedagogic, referring at the same time to analyze the Frankfurt school of philosophy and alluding to modern thinkers, including the pedagogues. Szkudlarek wrote about postmodernism, that it is a "culture of distraction, discontinuities, superficiality and

${ }^{30}$ R. Geisler, Jednostka $i$ społeczeństwo w postmodernizmie, Częstochowa 1999, p. 95-97.

${ }^{31} \mathrm{~J}$. Dybiec, Zagadnienie wartości w postmodernistycznej teorii i praktyce edukacyjnej, [in:] Edukacja - tradycja i wspótczesność, Eds. A. Majkowska, M. Łapot, Częstochowa 2013, p. 35, 37, 44.

${ }^{32}$ B. Śliwerski, Wspótczesne teorie i nurty, p. 367; S. Wołoszyn, Nauki o, p. 136-141. 
differences (...) challenging the foundations of our identity", ${ }^{33}$ while being a great challenge for pedagogic. In his book Knowledge and freedom in American postmodern pedagogic, this pedagogue observed that postmodernism has created an opportunity for educational discussion about human subjectivity, knowledge and freedom. Against the background of the American theory of educational programs (teaching) criticism, referring to the analysis of the representatives of the American critical pedagogy: Henry Armand Giroux and Peter McLaren, Szkudlarek had investigated the essence of these categories. Knowledge in postmodernism is a colloquial, based on the mass media and mass culture, is partial, local, associated with different mechanisms of governance, control and surveillance, however it is a culture and pedagogy of the most formative of human subjectivity. Similarly, pedagogy is a politics, that produces knowledge transfer in human relations controls and also develops human subjectivity. The analysis of these issues, particularly in reference to Giroux's theses, allow us to better understand the education of postmodernism. It aim is to "produce political entities", meaning to educate people who can reconcile the categories of difference and equality with the imperative of freedom and justice. It main goal is to include ethics, which as the social discourse refuses to consent to unnecessary suffering and exploitation and also has a focus on issues of difference, the experience with students, especially in the broader context of cultural identification. In the next step has to also capture intergroup differences and look for their links with the democratic functioning of society. Used language and conceptual apparatus are used to allow dealing with the issues of governance, social inequality, but also include the categories of exchange of ideas, dialogue, individual and social freedom. Education will include not one, but many cultural messages and appeal to diverse experiences as sources of knowledge. The knowledge itself is based not only by recourse to mind, but also of the body, emotions and feelings and intuition. In education has to be present all alternative visions of society and it should be allowed for students to think in utopian way, to believe in the possibility of changing the imperfect social reality, overcoming impotence, control and violence. The teacher as a "transformative intellectual" has to know the achievements of many cultures and use it in his work, he is involved in issues of social inequality, especially local ones and his role is to help overcome them. Postmodern education opposes all attempts of domination of one over the other, allows a "voice policy", leads to social and cultural transformation, including changes in education. ${ }^{34}$

${ }^{33}$ T. Szkudlarek, Wiedza i wolność w pedagogice amerykańskiego postmodernizmu, Kraków 1993, p. 90.

${ }_{34}$ Ibidem, p. 118-121; S. Wołoszyn, Nauki o wychowaniu, p. 138-141. 
B. Śliwerski sees postmodernism as "meth-theoretical perspective for the theory of upbringing and education", ${ }^{\prime}$, in which:

(...) it is break up with searching for the optimal education, in the same time raised doubts about any kind of interpersonal interactions in their entirety. The authority in postmodern pedagogy no longer apply, there is also no appeal to obey, comply with the standards of conduct by design, no oblige to any agreements, no community between partners. The dominant category is a voluntary society. ${ }^{36}$

In this pedagogic no longer poses questions about the goals and methods of education, but it is important which structures of interpersonal relations needs to be changed to eliminate violence, who should be called an expert to ensure that the pedagogic of pluralism, how to allow a maximum fulfillment to the unit, in order to determine critical, think and act politically. Values and norms are only helpful framework for the process. ${ }^{37}$ The teacher in postmodernism cannot decide for students or impose them his own interpretation of events and thus exclude them from the set of moral subjects. Recognizing the right to freedom of the students and in order to allow them to identify with their own thoughts and actions, the units in postmodern education have a chance to become the responsible and involved people. A democratic society should guarantee civil rights and freedom, and if state cannot do that, it should be changed. Also in science, including the pedagogic science, teaching should take into account the pluralism of paradigms without prejudging the truth of any. Keeping discourses between differing worldviews eliminates exclusion, helps maintain awareness of developments including the possible risks which are usually associated with an attempt to dominate from the supporters of the selected option. The assumptions of postmodern pedagogic are not a panacea for all the problems of education in the modern world, however, provide a new perspective for dealing with them, so they can be useful in the further development of humanistic education and the humanities in general.

\section{Summary - convergence and divergence of Kant's philosophy and pedagogic and postmodern pedagogic theses}

After comparison and interpretation of these assumptions compared systems it is justified to say that in philosophy, especially ethics, anthropology

\footnotetext{
${ }^{35}$ B. Śliwerski, Wspótczesne teorie i nurty, p. 358.

${ }^{36}$ Ibidem, p. 362.

${ }^{37}$ Ibidem, p. 363-364.
} 
and pedagogic of Kant we can find of many of the basic theses for postmodern pedagogic and sometimes they take the form of a mature and very contemporary.

It is obvious that Kant, by affecting especially the German cultural of pedagogic, based on the achievements of Neo-Kantianism, mainly from the Baden school, emphasizing of idealism and values, such as Wilhelm Windelband (1848-1915) and Heinrich Rickert (1863-1936), had significant influence on separation of the humanities science, including humanistic pedagogic, as independent from the naturalistic and positivist model of cognition. ${ }^{38}$ This process is still continued today, when postmodernism as a humanistic direction (idiographic) strongly criticizes and opposes the remains of scientist positivism in science.

In the postmodern pedagogic, essential elements are: knowledge, freedom and human subjectivity. The same categories are the focus of the theory of knowledge, ethics, anthropology and pedagogic of Kant. This scholar, building a theory of morality has based his postulated on the practical (moral) faith, the same just did the Max Horkheimer (1895-1973), who gave an essentially philosophical direction of the development of the Frankfurt School, so important for the development of postmodernism. Kant tried to reconcile rationalism and empiricism, creating their own epistemological position and the same did the representatives of the Frankfurt School, who did not want to tell clearly for any philosophical position, but dug out of them what they thought was most relevant. These representatives have generally negatively evaluated the scientific achievements of the Enlightenment, as inhibiting the development and emancipation of individuals and society. The theory of Baudrillard's hyper-reality looks very interesting, it cannot be separated from the semantic ontological reality of Kantian epistemology, in which the knower reality of the mind makes the synthesis of sensory data and concepts. To conclude - it can be seen that the characteristic of postmodernism, which is to enable and conduct discourses between different positions, was not strange to Kant.

In the views of Kant, there is no clear critical assessment of the socio-political contemporary societies, though he saw and negatively evaluated the low level of development is not so much a cultural and civilizational but moral one. Just as the representatives of critical pedagogic, he assumed that progress in education will change the surface of these societies. The path of changes understood as the social contract postulated by Rousseau, he rejected as unrealistic. Democratic society in the vision of Rousseau pose a threat to development and self-realization of individuals, which Kant also could not accept.

${ }^{38}$ J. Gajda, Pedagogika kultury, [in:] Encyklopedia pedagogiczna, p. 160-161. 
Focusing more on matter of pedagogic, it must be noted that according to Kant, knowledge should be transferred in the process of learning and teaching but not as complete and finished truth, but students and pedagogues must use some acquiring methods: Socratic and analytical, which is much closer to the demands of modern pedagogic. Kant took care of the appropriate conceptual apparatus, precisely defining the categories of language learning about morality. Also, postmodern pedagogic introduced new categories of educational resource to its terms in order to take into account new, so far not discussed in pedagogic phenomena and problems (political and intercultural) and do it in a way which creates hope for a positive solution.

Among the demands of Kant's morality, categories were associated with Christianity, God and the immortal soul, though Kant was aware of the existence of various religions, but did not deal with this pluralism. In this context, he reveals a discrepancy with the assumptions of postmodernism, clearly highlighting the diversity and differences. Although Kant is considered to be representative of open agnosticism and does not deal specifically religious issues, seems to contain his philosophy mainly in the conceptual categories of Western culture, Antique-Christian. Similarly, he is aware of gender differences in education, but generalizes education as education of boys, according to the spirit of his era.

The key to individuals and society development is the right education and what is the most important - moral education, both at school and beyond. Its purpose is to overcome the animal aspect of the man and his selfish desires, the development of talent, gaining control of his life and giving him moral and spiritual dimension. The pedagogues are very helpful in this process, they should be recruited from among the most mature morally people. Also in postmodern pedagogic, similar demands and hopes appear for the performance of duties: the moral and social teacher-educators. On the one hand his role is to be "transformative intellectual", engaged in a fair process of student's education and solving social problems and on the other - there is doubt associated with Bauman's "flickers" of identity in modern humans. The question is: the teacher, who is playing also Bauman's "player" role and feels that his existence is threatened in contemporary society, will put the good of the student or their own personal interests first? ${ }^{39}$

Compatible with Kantian ethics are also demands of postmodern pedagogic associated with rejection of authority, because only autonomous morality can provide moral development of a man. The next postulated postmodern "politics of voice", which is the essence of political activating of particular

39 P. Zieliński, Rola nauczyciela w świetle założeń edukacji postmodernistycznej, Prace Naukowe Akademii im. Jana Długosza w Częstochowie. Pedagogika, 2012, 21, p. 68-69. 
student, to a certain level also occurs in Kant's philosophy. Kant was a person, who demanded the abandonment of non-alignment posture, immobility, stagnation and dependence on others and he was encourage man to take his life into his own hands. He clearly presented this thesis in the text: What is Enlightenment? in which he wrote:

By enlightenment we called man's way out of minors, in which he fell from his own fault. This minor is the inability of man to use his own mind, without external guidance. This is a wrongful minor when it's caused not by lack of intellect, but the lack of decision and courage to use it without external management. Sapere aude! To Have the courage to use my own mind - this is the theme of the Enlightenment. ${ }^{40}$

Using this text, Kant also embraced the idea of activism, one of the main features of the latest New Education Movement, to which clearly refers postmodern pedagogic.

In this pedagogic, the knowledge is both culture and pedagogy that has the biggest influence on forms of human subjectivity. For Kant, knowledge is one of the most important components of the process of education. The other important component, human dignity is the main postulate of Kantian anthropology, the man deserves the respect in the society due to his morality. The postmodern pedagogic dignity is an essential attribute of human subjectivity.

The man, according to Kant, cannot develop himself morally and achieve autonomy of the will without freedom, or when someone is using coercion against him. Also in postmodernism it is assumed that in an atmosphere of freedom, liberty and riddance from authority and rejection of heteronomous morality sources, education takes on the character of a democratic and creative, reaching a level allowing self-creation to the individuals and real democratization of society. In the context of freedom, both in Kant as well as in postmodern education, the liable appears when a person somehow morally developed naturally reveals this side of personality.

Break up with the research of the optimal model of education in postmodernism reminds approach to Kant's moral principles. The scholar pointed to the categorical imperative, which can be derived more detailed standards of conduct. Also, postmodern pedagogic shows some general rules that determine how the elimination of coercion, allowing pluralism of ideas to education or voice policy can lead the process of education and upbringing. Probably the most important of them is voluntary, which can be associated with the p. 164

${ }^{40}$ I. Kant, Was is Aufklärung? trans. A. Landman, [in:] T. Kroński, Kant, Warszawa 1966, 
role of good will in Kantian ethics. Replacement coercive by voluntarism may be the most important postulate of educational postmodernism.

In presented pedagogical views, Kant's lack of commitment and spreading political aspect of education is visible, as well as lack of deeper analysis of social education, as is the case in postmodern pedagogic. That's why nobody can fully bind his philosophy and pedagogic with the assumptions of philosophy and postmodern pedagogic.

\section{BIBLIOGRAPHY}

Durozoi G., Roussel A., Filozofia. Stownik. Pojęcia, postacie, problemy [Philosophy. Dictionary. Concepts, characters, problems], WSiP, Warszawa 1997.

Dybiec J., Zagadnienie wartości w postmodernistycznej teorii i praktyce edukacyjnej, [in:] Edukacja - tradycja i wspótczesność [The problem of values in postmodern theory and educational practice [in:] Education - the tradition and modernisty], Eds. A. Majkowska, M. Łapot, Wydawnictwo im. S. Podobińskiego Akademii im. Jana Długosza w Częstochowie, Częstochowa 2013.

Gajda J., Pedagogika kultury, [in:] Encyklopedia pedagogiczna XXI wieku, t. 4, P, [The pedagogic of culture [in:] The pedagogical encyclopedia of XXI century, vol. 4, P], Ed. T. Pilch, Wydawnictwo Akademickie Żak, Warszawa 2003.

Geisler R., Jednostka i społeczeństwo w postmodernizmie [The unit and society in postmodernism], Wydawnictwo WSP w Częstochowie, Częstochowa 1999.

Hejnicka-Bezwińska T., Pedagogika pozytywistyczna, [in:] Pedagogika, t. 1 [Pedagogic of positivism, [in:] The education, vol. 1 ], red. Z. Kwieciński, B. Śliwerski, WN PWN, Warszawa 2004.

Jameson F., Postmodernizm i społeczeństwo konsumpcyjne, trans. P. Czapliński, [in:] Postmodernizm. Antologia przekładów [Postmodernism and Consumer Society, trans. P. Czapliński, [in:] Postmodernism. Anthology of translations], Ed. R. Nycz, Baran i Suszczyński, Kraków 1997.

Kant I., Krytyka władzy sadzenia [The critique of judgment ], trans. J. Gałecki, Wydawnictwo Naukowe PWN, Warszawa 1986.

Kant. I., O pedagogice [About pedagogic], trans. D. Sztobryn, Dajas, Łódź 1999.

Kant I., Krytyka praktycznego rozumu [The critique of practical mind ], trans. J. Gałecki, wyd. 3, Wydawnictwo Naukowe PWN, Warszawa 2011.

Kroński T., Kant, Wiedza Powszechna, Warszawa 1966.

Kwaśnica R., Dwie racjonalności. Od filozofii sensu ku pedagogice ogólnej [Two rationality. From philosophy of sense to general pedagogic], IKN ODN, Wrocław 1987.

Lyotard J.F., Kondycja ponowoczesna. Raport o stanie wiedzy [The Postmodern Condition: Report on Knowledge], trans. M. Kowalska, J. Migasiński, Fundacja Aletheia, Warszawa 1997.

Lyotard J.F., Poróżnienie [The rupture], trans. B. Banasiak, Wydawnictwo Uniwersytetu Jagiellońskiego, Kraków 2010.

Melosik Z., Pedagogika pragmatyzmu, [in:] Pedagogika, t. 1 [Pedagogic of pragmatism, [in:] The Education, vol. 1], red. Z. Kwieciński, B. Śliwerski, WN PWN, Warszawa 2004.

Rousseau J.J., Umowa społeczna [The Social Contract], trans. A. Peretiatkowicz, Antyk, Kęty 2002. 
Somr M., Hruškova L., Herbart's Philosophy of Pedagogy and Educational Teaching, Studia Edukacyjne, 2014, 33.

Szczęsny W.W., Kant Immanuel, [in:] Encyklopedia pedagogiczna XXI wieku, t. 2, G-乇 [Kant Immanuel, [in:] The pedagogical encyclopedia of XXI century, vol. 2, G-L], Ed. T. Pilch, Wydawnictwo Akademickie Żak, Warszawa 2003.

Szkudlarek T., Wiedza i wolność w pedagogice amerykańskiego postmodernizmu [Knowledge and freedom in American postmodern pedagogic], Oficyna Wydawnicza Impuls, Kraków 1993.

Sztobryn S., Stowo wstęne [in:] I. Kant, O pedagogice [The foreword [in:] I. Kant, About pedagogic], Dajas, Łódź 1999.

Śliwerski B., Wspótczesne teorie i nurty wychowania [The contemporary theories and trends of education], Oficyna Wydawnicza Impuls, Kraków 1998.

Tchorzewski A.M. de, Teoria wychowania, [in:] Encyklopedia pedagogiczna XXI wieku, t. 6, $\mathrm{Su}-U$ [The theory of education, [in:] The pedagogical encyclopedia of XXI century, vol. 6, Su-U ], Ed. T. Pilch, Wydawnictwo Akademickie Żak, Warszawa 2007.

Wołoszyn S., Nauki o wychowaniu w Polsce w XX wieku. Próba syntetycznego zarysu na tle powszechnym [The science of education in Poland in the twentieth century. Assay about the outline of a synthetic universal], wyd. 2 poszerz., Dom Wydawniczy „Strzelec", Kielce 1998.

Zieliński P., Rola nauczyciela w świetle założeń edukacji postmodernistycznej, [The role of a teacher in the light of the principles of postmodernist education] Prace Naukowe Akademii im. Jana Długosza w Częstochowie. Pedagogika, 2012, 21.

Zieliński P., Kantowskie inspiracje pedagogiki humanistycznej [The Kantian's Inspiration in Humanist Pedagogy], Prace Naukowe Akademii im. Jana Długosza w Częstochowie. Rocznik Polsko-Ukraiński, 2014, 16. 